\title{
KUALITAS BAHAN KERING DAN BAHAN ORGANIK PAKAN KOMPLIT FERMENTASI BERBASIS GAMAL (Gliricidia sepium) DI DAERAH LAHAN KERING KEPULAUAN
}

\section{The Quality of Dry and Organic Ingredients, Gamal-Based Fermentation Completes (Gliricidia sepium) In The Dry Area of The Archipelago}

\author{
Bambang Hadisutanto ${ }^{1}$, Johanis A. Jermias ${ }^{1}$, dan Winda Wahyu Absari ${ }^{2}$ \\ ${ }^{1}$ Program Studi Produksi Ternak, Jurusan Peternakan, Politeknik Pertanian Negeri Kupang \\ ${ }^{2}$ Program Studi Teknologi Pakan Ternak, Jurusan Peternakan, \\ Politeknik Pertanian Negeri Kupang \\ Email: bhadisutanto@gmail.com
}

\begin{abstract}
ABSTRAK
Pakan komplit merupakan pakan dengan kandungan nutrien lengkap yang dibuat dari campuran bahan pakan hijauan gamal, klobot jagung, dedak padi, tepung putak dan tepung ikan dengan perbandingan tertentu dan dalam bentuk homogen untuk diberikan sebagai pakan yang dapat memenuhi kebutuhan pokok ternak, produksi dan reproduksi tanpa tambahan pakan lain. Penelitian ini bertujuan untuk menjelaskan pengaruh lama fermentasi pakan komplit terhadap kandungan bahan kering dan bahan organik. Penelitian ini menggunakan Rancangan Acak Lengkap dengan 4 perlakuan dan 5 ulangan yaitu LF 0 (Lama Fermentasi 0 minggu), LF 3 (Lama Fermentasi 3 minggu), LF 6 (Lama Fermentasi 6 minggu dan LF 9 (Lama Fermentasi 9 minggu). Analisis statistik menunjukkan bahwa kadar bahan kering pakan komplit dengan lama fermentasi 0 minggu berbeda nyata dengan 3, 6 dan 9 minggu lama fermentasi. Sedangkan kadar bahan organik dengan lama fermentasi 6 minggu berbeda nyata dengan 0, 3 dan 9 minggu lama fermentasi $(\mathrm{P}<0,05)$. Kesimpulan dari hasil penelitian pakan komplit fermentasi berbasis gamal yaitu lama fermentasi 0 minggu dan 3 minggu memiliki kualitas nutrien terbaik dibandingkan dengan lama fermentasi 6 minggu dan 9 minggu.
\end{abstract}

Kata kunci: Gamal, Kualitas Nutrien, Lama Fermentasi

\begin{abstract}
Complete feed is feed with complete nutrient content made from a mixture of gamal forage, corn husks, rice bran, putak flour and fish meal with a certain ratio and in a homogeneous form to be given as feed that can meet the basic needs of livestock, production and reproduction without additional feed. This study aims to explain the effect of complete feed fermentation time on dry matter and organic matter content. This study used a completely randomized design with 4 treatments and 5 replications, namely LF 0 (fermentation time 0 weeks), LF 3 (fermentation time 3 weeks), LF 6 (fermentation time 6 weeks and LF 9 (fermentation time 9 weeks). Statistical analysis showed that the dry matter content of complete feed with fermentation time of 0 weeks was significantly different from 3, 6, and 9 weeks of fermentation time, while the content of organic matter with fermentation time of 6 weeks was significantly different from 0,3 , and 9 weeks of fermentation time $(P<0.05)$. The conclusion from the research results of gamal-based complete fermentation is that the fermentation time of 0 weeks and 3 weeks has the best nutrient quality compared to the fermentation time of 6 weeks and 9 weeks.
\end{abstract}

Keywords: Gamal, Nutrient Quality, Fermented Duration 


\section{PENDAHULUAN}

Produktivitas ternak dipengaruhi oleh tiga pilar usaha ternak, yaitu breeding, feeding dan management (Amam d\& Harsita, 2019). Bahan pakan merupakan salah satu faktor pakan yang berhubungan dengan produktivitas ternak. Bahan pakan ternak adalah bahan yang dapat dimakan, dicerna dan digunakan oleh ternak. Pada umumnya tanaman menjadi sumber pakan utama bagi ternak kambing untuk kelangsungan hidupnya atau untuk kebutuhan hidup pokok dan sintesa jaringan tubuh.

Sumber daya lokal yang banyak tersedia di antaranya daun gamal, klobot atau kulit jagung, tepung putak, dedak padi dan tepung ikan. Gamal (Gliricidia sepium) merupakan salah satu hijauan yang disukai oleh ternak ruminansia. Tanaman ini tumbuh subur di daerah lahan kering seperti Kupang dan hampir tersedia sepanjang tahun walaupun volume daunnya tidak sebanyak waktu musim hujan. Klobot atau kulit buah jagung merupakan limbah yang tidak dimanfaatkan. Klobot jagung dari jenis jagung pulut ini banyak dijumpai di sentra penjualan jagung siap saji di desa Oesao kecamatan Kupang Timur. Tepung putak yang diproduksi oleh industri rumah tangga petani di desa Oelamasi merupakan sumber pakan yang tidak bersaing dengan kebutuhan manusia. Tepung ikan non pabrikan yang berasal dari remukan atau ikan yang hancur hasil pembuatan ikan asin di pasar ikan Oesapa Kupang yang tidak memiliki nilai ekonomi lagi.

Sebagai unsur utama pakan komplit fermentasi digunakan daun gamal dengan imbangan atau persentase paling besar mengingat akan dimanfaatkan oleh rumunansia kecil (kambing), sedangkan campuran lain seperti klobot jagung, dedak padi, tepung putak dan tepung ikan yang akan melengkapi kebutuhan nutrien ternak tersebut dan juga merupakan biokatalisator dalam proses fermentasi pakan komplit terutama dedak padi.

Permasalahan yang sering dihadapi peternak adalah kurangnya ketersediaan pakan baik dalam mutu maupun jumlahnya, sebagai contoh adalah limbah hasil samping pertanian dan pangan seperti jerami jagung dan jerami padi. Kadar nutrien yang rendah akan memengaruhi kecernaan pakan dan ketersediaan nutrien sehingga produktivitas ternak juga rendah.

Pemanfaatan sumber daya lokal terutama daun gamal (Gliricidia sepium) harus dilakukan secara maksimal merupakan langkah strategis dalam mencapai efisiensi produksi kambing. Keragaman bahan baku pakan yang tinggi menawarkan fleksibilitas yang tinggi bagi peternak, namun juga menawarkan kompleksitas bagi Nutrienonis agar dapat dimanfaatkan secara efisien. Dari segi kuantitas, maka pakan lokal berserat tinggi (lignoselulosa) merupakan yang terbesar (Pamungkas, 2011).

Beberapa kendala dalam pemanfaatan hasil sisa tanaman adalah 1) palatabilitas rendah, 2) nilai nutrien rendah, 3) penanganan relatif sulit (pengeringan, penggilingan, transportasi, dan fermentasi), dan 4) ketersediaan musiman. Salah satu cara yang dapat dilakukan untuk mengatasi permasalahan pakan terutama pada musim kering adalah dengan fermentasi pakan dalam bentuk pakan komplit fermentasi berbasis gamal. Peningkatan kualitas pakan dapat dilaksanakan dengan memformulasikan bahan-bahan limbah pertanian, industri pertanian dan pangan menjadi formula dalam bentuk pakan komplit fermentasi melalui suatu proses fermentasi.

Fermentasi merupakan salah satu teknologi untuk meningkatkan kualitas pakan asal limbah ataupun pakan lokal, karena keterlibatan mikroorganisme dalam mendegradasi serat kasar, mengurangi kadar lignin dan senyawa anti nutrisi, sehingga nilai kecernaan pakan dapat meningkat (Astuti et al., 2017). Namun informasi mengenai berapa lama fermentasi yang dibutuhkan untuk menghasilkan kualitas terbaik pakan komplit fermentasi yang bersumber dari pakan lokal dan limbah pertanian belum banyak diungkapkan. 


\section{METODE}

\section{Materi}

Bahan yang digunakan dalam penelitian ini berupa Daun Gamal (Gliricidia sepium),Tepung putak, Dedak padi, Klobot/kulit buah jagung Pulut, Tepung ikan non pabrikan, Stiker, nama/label, lakban warna hitam, karung volume $50 \mathrm{~kg}$, kantong plastik Poly Carbonat volume $5 \mathrm{~kg}$ dengan ketebalan $0,8 \mathrm{~mm}$.

\section{Persiapan Penelitian}

\section{Prosedur Penelitian}

Menyiapkan putak untuk diproses menjadi tepung putak, tepung ikan dari nelayan penjual ikan kering, kantung PC (Poly Carbonat) dengan ketebalan 0,8 mm dengan volume $5 \mathrm{~kg}$, daun gamal yang sudah dilayukan hingga rataan kadar air berkurang sekitar $40 \%$ (tidak dicincang), klobot atau kulit buah jagung Pulut. Kulit buah jagung dicincang hingga mempunyai ukuran kecil serta menyusun formulasi pakan komplit fermentasi berbasis gamal.

\section{Pelaksanaan Penelitian}

Memasukkan bahan pakan penelitian ke dalam kantong PC (Poly Carbonat) sebanyak $5 \mathrm{~kg}$ untuk setiap unit perlakuan sehingga total terdapat 20 kantong unit penelitian, Memasukkan bahan pakan ke dalam kantong PC dilakukan untuk perlakuan LF9 lebih dulu, baru menyusul berikutnya LF6, LF3 dan LF0 dengan rentang antar perlakuan selama 3 minggu. Hal tersebut dilakukan agar saat panen, uji kualitas nutrien dilakukan serentak untuk setiap perlakuan penelitian. Melakukan fermentasi secara kedap udara terhadap setiap kantong penelitian yang terdiri dari perlakuan LF0 disimpan selama 0 minggu, LF3 disimpan selama 3 minggu, LF6 disimpan selama 6 minggu dan LF9 disimpan selama 9 minggu. Melakukan pengambilan sampel dari pakan komplit fermentasi berbasis gamal sesuai lama fermentasi sebanyak 100 gram, yang selanjutnya dikeringkan dalam oven pada suhu $60^{\circ} \mathrm{C}$ hingga suhu tersebut stabil. Melakukan analisis kualitas nutrien pada setiap sampel penelitian sebanyak 20 sampel penelitian menggunakan metode AOAC ( Association of Official Analitical Chemist) yaitu metode analisis proksimat standar Internasional di laboratorium.

\section{Analisis Data}

Penelitian ini menggunakan Rancangan Acak Lengkap (RAL) dengan 4 perlakuan dan 5 ulangan. Perlakuan terdiri dari Lama Fermentasi (LF) 0 minggu, (LF) 3 minggu, (LF) 6 minggu dan (LF) 9 minggu. Data hasil penelitian yang diperoleh dianalisis dengan menggunakan sidik ragam (Anova). Data yang memberikan hasil nyata dilanjutkan dengan DMRT (Duncan's Multiple Range Test) (Gaspersz, 1991).

\section{HASIL DAN PEMBAHASAN}

\section{Bahan Kering Pakan Komplit Fermentasi}

Analisis ragam kadar bahan kering pakan komplit fermentasi menunjukkan bahwa lama fermentasi berpengaruh nyata $(\mathrm{P}<0,05)$ terhadap bahan kering. Kadar bahan kering $(\% \mathrm{BK})$ pada masing perlakuan yaitu Lama Fermentasi (LF) 0 minggu sebesar 94,93\%, LF 3 minggu sebesar 94,06\%, LF 6 minggu sebesar 93,25\% dan LF 9 minggu sebesar 93,77\% (Grafik 1). Dari Grafik 1. dapat dilihat bahwa adanya perbedaan kadar bahan kering selama fermentasi 3 minggu, 6 dan 9 minggu dibandingkan dengan 0 minggu tanpa fermentasi. Hal ini disebabkan karena pada fermentasi pakan komplit terjadi aktivitas fermentasi oleh mikroba yang tinggi yang menghasilkan asam laktat sehingga terjadi penurunan kadar bahan kering. 
Tingginya aktivitas fermentasi menyebabkan produksi H2O meningkat. Peningkatan kadar air selama proses ensilase menyebabkan penurunan kadar bahan kering. Hasil penelitian Mirzah \& Muis (2015) menyatakan bahwa lamanya waktu fermentasi menyebabkan banyak bahan yang dirombak oleh enzim tetapi dengan bertambahnya waktu fermentasi ketersedian nutrien pada media fermentasi habis sehingga mikroba lama kelamaan akan mati. Penurunan bahan kering pakan komplit fermentasi merupakan hasil dari metabolisme mikroba. Keberadaan mikroba akan mengakibatkan peningkatan kadar air yang dihasilkan sehingga kadar bahan kering akan semakin rendah (Mirzah \& Muis, 2015; Suningsih et al., 2019).

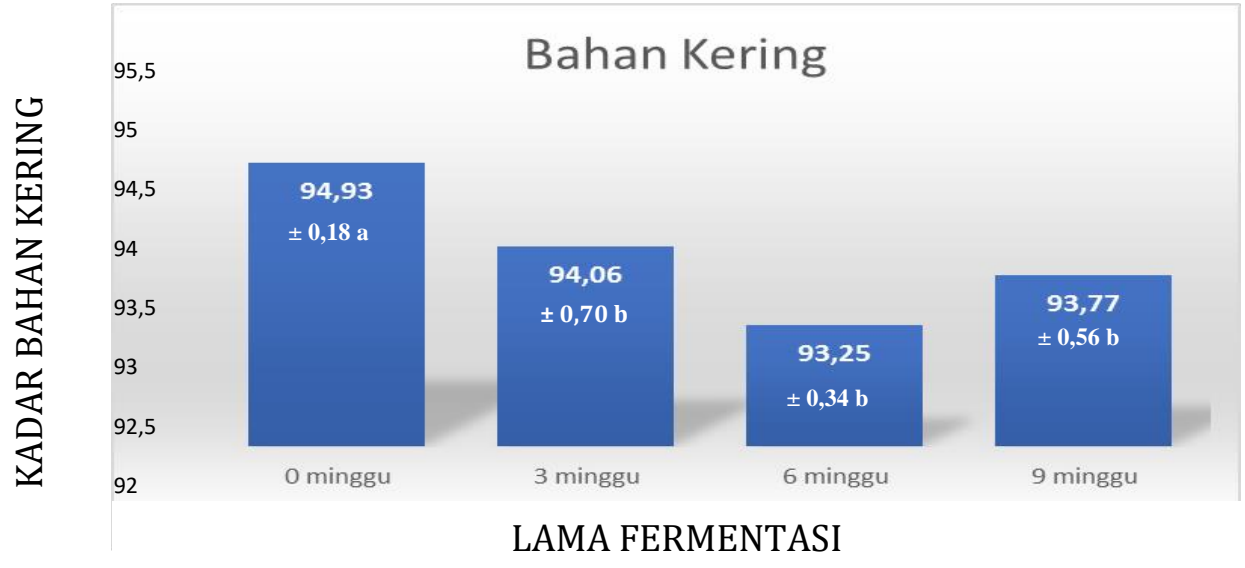

Grafik 1. Rataan Kadar Bahan Kering Pakan Komplit Fermentasi (\%)

\section{Bahan Organik Pakan Komplit Fermentasi}

Analisis ragam kadar bahan organik pakan komplit fermentasi menunjukkan bahwa lama fermentasi berpengaruh nyata $(\mathrm{P}<0,05)$ terhadap bahan organik. Kadar bahan organik $(\% \mathrm{BO})$ pada masing perlakuan yaitu LF 0 minggu sebesar 82,09\%, LF 3 minggu sebesar 79,97\%, LF 6 minggu sebesar 78,17\% dan LF 9 minggu sebesar 81,19\% (Grafik 2).

Secara uji statistik (bukan biologis) Duncan's Multiple Range Test (DMRT) diperoleh bahwa kadar bahan organik menunjukkan hasil yang berbeda lama fermentasi 6 minggu dengan 0 minggu, 3, dan 9 minggu. Hal ini berarti bahwa lama fermentasi 0 minggu, 3 minggu dan 9 minggu secara statistik hasilnya sama atau tidak berbeda. Sedangkan pakan komplit dengan lama fermentasi 6 minggu, secara statistik menunjukkan perbedaan, artinya lama fermentasi 6 minggu berbeda atau tidak sama dengan 0 minggu, 3 minggu, dan 9 minggu.

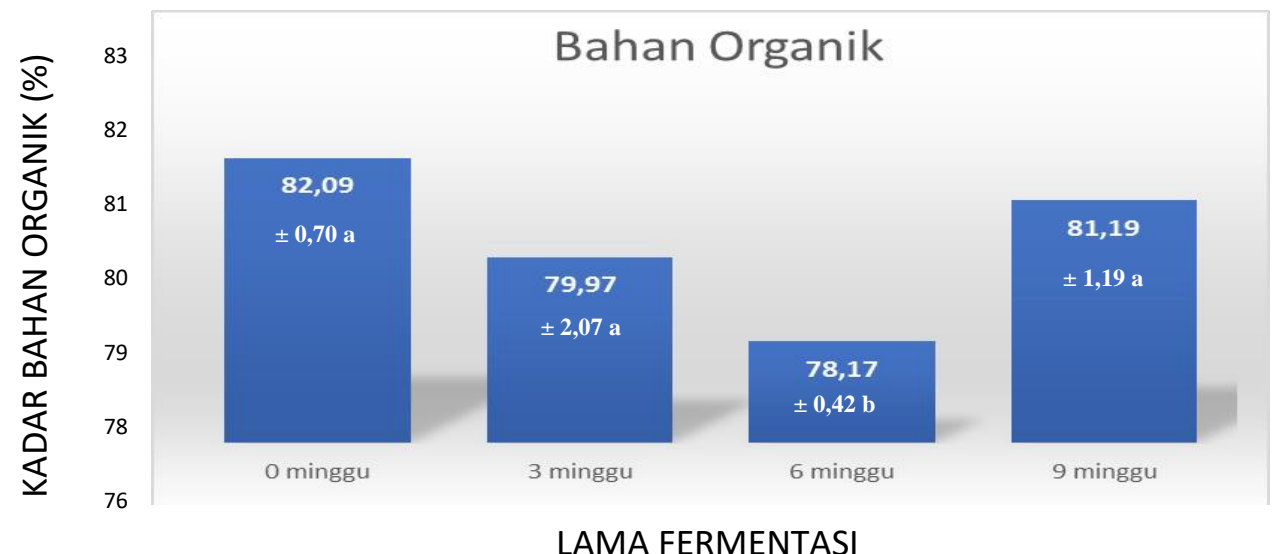

Grafik 2. Rataan Kadar Bahan Organik Pakan Komplit Fermentasi (\%) 
Terjadinya penurunan kadar bahan organik pada lama fermentasi 6 minggu diduga terjadinya peningkatan konsentrasi di dalam produk karena berbagai perubahan bahan organik akibat proses biokonversi yang menghasilkan H2O dan CO2 (Fardiaz, 1988 dikutip dari Samadi et al., 2015). Hal lain yang menyebabkan penurunan bahan organik pakan komplit fermentasi lama fermentasi 6 minggu adalah kemungkinan aktivitas mikroba pada proses fermentasi yang menyebabkan terjadi pemecahan kadar substrat (dedak padi dan tepung putak) sehingga mempermudah mikroorganisme yang ada untuk mencerna bahan organik, dan hasil fermentasi bahan organik melepaskan gula, alkohol dan asam amino (Astuti et al., 2017). Penurunan kadar abu ini dapat terjadi karena dalam proses fermentasi akan terjadi peningkatan bahan organik, karena adanya proses degradasi bahan (substrat) oleh mikroba. Semakin sedikit bahan organik yang terdegradasi, maka relatif semakin sedikit juga terjadinya penurunan kadar abu secara proporsional, sebaliknya semakin banyak bahan organik yang terdegradasi maka relatif semakin banyak juga terjadinya peningkatan kadar abu secara proporsional (Styawati et al., 2013).

\section{KESIMPULAN}

Kesimpulan yang didapat dari penelitian ini adalah lama fermentasi 0 minggu dan 3 minggu memiliki kualitas nutrien terbaik dibandingkan dengan lama fermentasi 6 minggu dan 9 minggu. Hasil pembahasan tersebut, saran yang dapat disampaikan pada peternak adalah menggunakan pakan komplit fermentasi 0 minggu kecuali pada musim hujan dengan kondisi daun gamal melimpah maka disarankan menggunakan pakan komplit fermentasi 3 minggu.

\section{DAFTAR PUSTAKA}

Astuti, T., M.N. Rofiq \& Nurhaita. (2017). Evaluasi kadar bahan kering, bahan organik dan protein kasar pelepah sawit fermentasi dengan penambahan sumber karbohidrat. Jurnal Peternakan, 14(2), 42-47. http://dx.doi.org/10.24014/jupet.v14i2.4247.

Amam \& P. A. Harsita. (2019). Tiga pilar usaha ternak: breeding, feeding and management. Jurnal Sain Peternakan, 14(4), 431-439. https://doi.org/10.31186/jspi.id.14.4.431-439.

Fardiaz, (1998), Mikrobiologi Pangan, Departemen Pendidikan dan Kebudayaan. Bogor: Institut Pertanian Bogor Press.

Gasperst, V. (1991). Metode Perancangan Percobaan. Bandung: CV Armico.

Mirzah \& Muis. (2015). Peningkatan kualiats nutrisi limbah kulit ubi kayu melalui fermentasi menggunakan Bacillus amyloliquefaciens. Jurnal Peternakan Indonesia, 17(2), 131-142. https://doi.org/10.25077/jpi.17.2.131-142.2015.

Pamungkas. W. (2011). Teknologi fermentasi, alternatif solusi dalam upaya pemanfaatan bahan pakan lokal. Media Akuakultur, 6(1), 43-48. http://dx.doi.org/10.15578/ma.6.1.2011.43-48.

Styawati, N.E, Muhtarudin \& Liman.( 2013). Pengaruh lama fermentasi Trametes sp. terhadap kadar bahan kering, kadar abu dan kadar serat kasar daun nenas varietas Smooth cayene. Fakultas Pertanian Universitas Lampung.

Suningsih, N., W. Ibrahim., O. Liandris \& R. Yulianti. (2019). Kualitas fisik dan nutrisi jerami padi fermentasi pada berbagai penambahan starter. Jurnal Sains Peternakan Indonesia, 14(2), 191200. https://doi.org/10.31186/jspi.id.14.2.191-200. 